\title{
Our Experiences in Acute Arterial Embolism Treatment with Endovascular Techniques in Lower Extremity
}

\section{Endovasküler Yöntemlerle Tedavi Ettiğimiz Akut Alt Ekstremite Emboli Deneyimlerimiz}

\author{
${ }^{1}$ Mehmet Atay (D), ${ }^{2}$ Onur Saydam (D)
}

\begin{abstract}
'Bahçelievler Devlet Hastanesi Kalp ve Damar Cerrahi Kliniği, İstanbul

${ }^{2}$ Tepecik Eğitim ve Arasstırma Hastanesi, Kalp ve Damar Cerrahi Kliniği, Izmir

Correspondence

Mehmet Atay, Kocasinan Merkez Karadeniz Cd. No:48, Bahçelievler Devlet Hastanesi Kalp ve Damar Cerrahi Birimi 34186 Bahçelievler/istanbul

E-Mail: drataym@gmail.com

How to cite?

Atay M, Saydam O. Our Experiences in Acute Arterial Embolism Treatment with Endovascular Techniques in Lower Extremity. Genel Tip Derg. 2022;32(1):3944.
\end{abstract}

\begin{abstract}
Objectives: The study aims to retrospectively evaluate the 1-year results of endovascular treatment with rheolytic thrombectomy or catheter-directed thrombolytic infusion therapy in acute femoropopliteal bypass graft occlusion.

Methods: The patients who had a history of femoro-popliteal by-pass operation and during their follow-up diagnosed with ipsilateral acute limb ischemia between 2016 and 2018 were included. The total of 13 patients were included and they were divided into two groups according to their treatment methods. (Rheolytic thrombectomy (RT): 8; catheter-directed thromolytic infusion (CDT): 5).

Results: There was no statistically significant difference between the two groups in terms of demographic data and Rutherford embolism classification. RT and CDT infusion primary patency values were $87.5 \%$ and $80 \%$ for 6 months, $75 \%$ and $60 \%$ for 12 months, respectively. Secondary patency values were found to be $100 \%$ in both groups for 6 months, and $87.5 \%$ and $80 \%$ for 12 months, respectively. There was no significant difference between the two groups in terms of primary and secondary patency.

Conclusion: Endovascular therapy can be preferred in the treatment of acute femoro-popliteal by-pass graft occlusion in selected patient groups due to its less invasiveness, early mobilization, and low mortality and morbidity rates compared to surgery.

Keywords: acute limb ischemia, catheter-directed thrombolytic therapy, rheolytic thrombectomy

Öz

Amaç: Çalışmada akut femoro-popliteal baypas greft oklüzyonunda reolitik trombektomi veya kateter aracılı trombolitik infüzyon tedavisi ile endovasküler tedavinin 1 yıllık sonuçlarını retrospektif kateter aracılı trombolitik infüzyon tediçadık.
olarak değerlendirmeyi amaçladi

Yöntem: 2016-2018 yılları arasında daha önceden femoropopliteal baypas operasyonu geçiren ve takipleri sırasında ipsilateral akut ekstremite iskemisi tanısı alan 13 hasta çalısmaya dahil edildi. Hastalar tedavi yöntemlerine göre iki ayrı gruba ayrıldı. (Reolitik trombektomi (RT): 8; Kateter aracılı trombolitik infüzyonu (KAT): 5).

Bulgular: İki grup arasında demografik veriler ve Rutherford emboli sınıflaması açısından anlamlı fark yoktu. RT ve KAT infüzyon tedavi gruplarında primer patensi 6 ay için sırasıyla \%87,5 ve \%80, 12 ay için \%75 ve \%60 idi. Sekonder patensi her iki grupta 6 ay için \%100, 12 ay için sırasıyla \%87,5 ve \%80 bulundu. Primer ve sekonder patensi açısından iki grup arasında anlamlı fark saptanmadı.

Sonuçlar: Akut femoropopliteal greft oklüzyonu tedavisinde cerrahiye göre daha az invaziv olması ve erken mobilizasyon, düşük mortalite ve morbidite oranları nedeniyle seçilmiş hasta grubunda endovasküler tedavi tercih edilebilir.

Anahtar Kelimeler: akut ekstremite iskemisi, kateter aracilı trombolitik, reolitik trombektomi
\end{abstract}

\section{Introduction}

Acute limb ischemia (ALI) is a clinical picture that with history of femoro-popliteal bypass (FPB) (2). threatens limb viability (1). ALI is characterized by sudden deterioration in limb perfusion which can develop on an embolic or thrombotic background is one of the important causes of morbidity and mortality $(2,3)$.

One of the most important reasons why alternative methods come to the fore in acute on chronic peripheral arterial disease patients is that conventional embolectomy cannot be performed selectively due to status of outflow arteries, especially in vessels below Embolectomy surgery has survived without serious the knee, and as a result, complete revascularization modifications since the development of the cannot be achieved. Besides, the higher incidence of embolectomy catheter by Thomas Fogarty in 1963 complications of surgical embolectomy in cases with and is still considered the gold standard treatment in accompanying chronic peripheral artery disease and ALI $(4,5)$. However, with the developing technologies, the need for additional interventions for complete less invasive endovascular methods have been begun revascularization can be counted as another reason. to be used more frequently in ALI especially in patient (6). 
Among the endovascular treatments, the most commonly used alternatives to embolectomy are percutaneous mechanical thrombectomy, rheolytic thrombectomy (RT), and catheter-directed thrombolytic (CDT) treatments (6). These treatment methods can be used individually or in combination with each other or with additional endovascular methods such as balloon angioplasty, stent implantation and/or atherectomy $(7,8)$. Although endovascular methods have theoretical advantages, there are still debates regarding the safety and efficacy of the procedure in practice.

For this reason, in the present study, it is aimed to present the early results of patients with FPB history and were diagnosed ipsilateral acute lower extremity ischemia by imaging methods and were therefore treated with RT and/or CDT.

\section{Materials and Methods}

Thirteen patients with ALI due to acute FPB graft occlusion and underwent endovascular treatment with RT or CDT between 2016 and 2018 were included. The patients' clinical information, demographic data and past intervention histories were scanned retrospectively from files and electronic media.

The study protocol was approved by the Bakırköy Dr. Sadi Konuk Training and Research Hospital Ethics Committee (Approval Date: 15/1 1/2021, No: 2021/494).

Patients older than 18 years of age with a history of FPB operation and had 4 or more symptoms or signs according to Rutherford classification as a result of acute FPB graft occlusion were included in the study. Patients with motor and sensory deficits and irreversible ischemia, patients with an estimated duration of intraluminal thrombus older than 14 days, patients with contraindications to antiplatelet therapy, anticoagulants or thrombolytic drugs, and patients with life-threatening contrast allergy were excluded from the study.

In addition to clinical evaluation, color Doppler ultrasonography (CDU) was initially performed for the patients. Computed tomography angiography (CTA) imaging was applied to patients whose CDU results were significant in terms of acute FPB graft occlusion. (Figure-1)

After the diagnosis of acute FPB graft occlusion, all patients were admitted to the intensive care unit (ICU). A loading dose of 5000 IU of unfractionated heparin was given and infusion was initiated to keep the activated partial thromboplastin time at twice the control level. Fluid resuscitation was also initiated with a dose of $100 \mathrm{ml} /$ hour. Patients were followed up at 6-hour intervals with hemogram, coagulation factors, kidney, and liver markers.

Emergency intervention was planned for the patients, and they were processed on the same day they were admitted to the hospital. All patients underwent endovascular treatment either with RT or CDT infusion.

The patients were placed in the supine position. All procedures were performed under hemodynamic monitoring and local anesthesia. Arterial intervention in the patients was planned as retrograde crossover from the contralateral leg.

After the sheath was introduced under the guidance of ultrasonography, the procedure was initiated with the control of activated coagulation time. The graft occlusion was passed using a 0.035 hydrophilic guidewire with a guidance of 5-Fr straight tip or angled guide catheter.

Thrombolytic infusion was performed as continuous infusion with valved Infusion Catheters (The CraggMcNamaraTM Micro Therapeutics Infusion Catheter, Medtronic, USA) or with "power pulse" mode of RT (AngioJetTM, Boston Scientific, USA) according to operator preference and experience. (Figure-2)

Figure-1. 3D examination image in angiographic computed tomography. A: Pre-operative view of total occluded graft. B: endovascular procedure and $12^{\text {th }}$ month graft appearance in the follow-up period

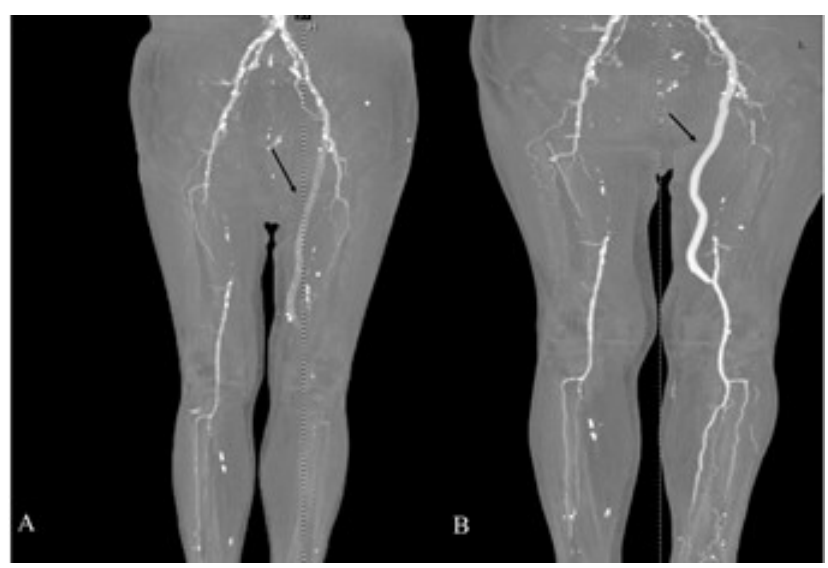

Under "power-pulse" mode device make direct thrombolytic infusion into the thrombus in order to make aspiration more efficient in patients who underwent RT. For this, it was prepared to be given during RT with $10 \mathrm{mg}$ of TPA in $50 \mathrm{~mL}$ of physiological saline. During the procedure, arteriography was performed intermittently to localize the thrombus. The RT duration did not exceed 480 seconds to prevent hemolysis and other complications. In case of residual thrombus in the final angiogram, the procedure was not prolonged and selective thrombolytic infusion was administered for 24 hours against residual thrombus.

In patients who underwent CDT, alteplase (tPA, Actilyse, flacon 50mg, Boehringer Ingelheim Gmbh, Ingelheim am Rhein, Germany) was given as a bolus by diluting $10 \mathrm{mg}$ in sheath exactly with isotonic (9). 10 minutes later thrombolysis, the catheter was inserted into the thrombus and TPA infusion of $1 \mathrm{mg} / \mathrm{h}$ was started. The laboratory's normal reference range of fibrinogen was 170-420 mg/dL. Below $170 \mathrm{mg} / \mathrm{dL}$, the tPA dose decreased to $0.5 \mathrm{mg} / \mathrm{h}$. Below $100 \mathrm{mg} / \mathrm{dL}$, tPA infusion was stopped. Control arteriography was performed at the end of the first 24 hours. Patients with residual thrombus were given an additional 12 hours of thrombolytic infusion (Figure-3). 
Figure-2. Patient treated with endovascular methods. A: preoperative angiographic view, PTFE graft total occluded, B: The lesion was crossed with a wire, after the thrombolytic infusion, aspiration and thrombectomy with the help of a catheter, C: Presence of residual thrombus in post-catheter imaging, D: Balloon angioplasty into the graft, 1: proximal segment, 2: Distal segment

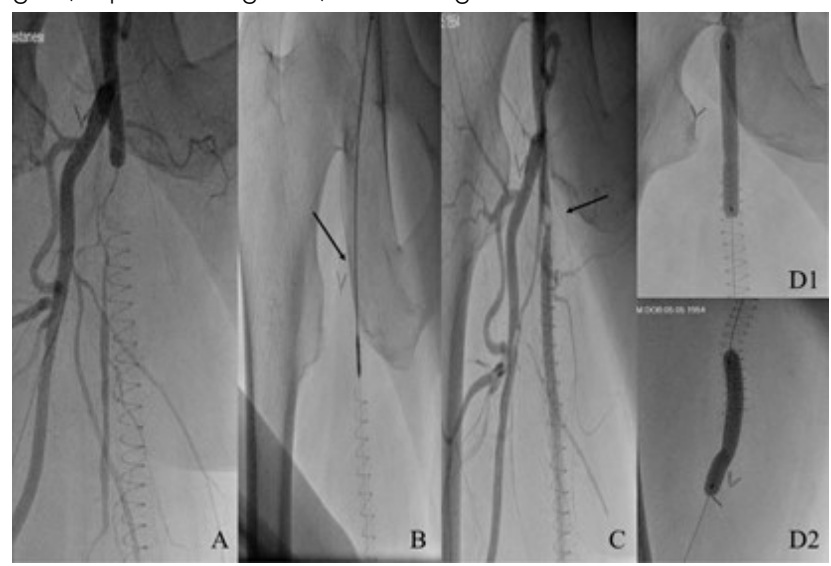

Figure-3. Control angiography after completion of 24-hour thrombolytic infusion, A: proximal segment, B: distal segment

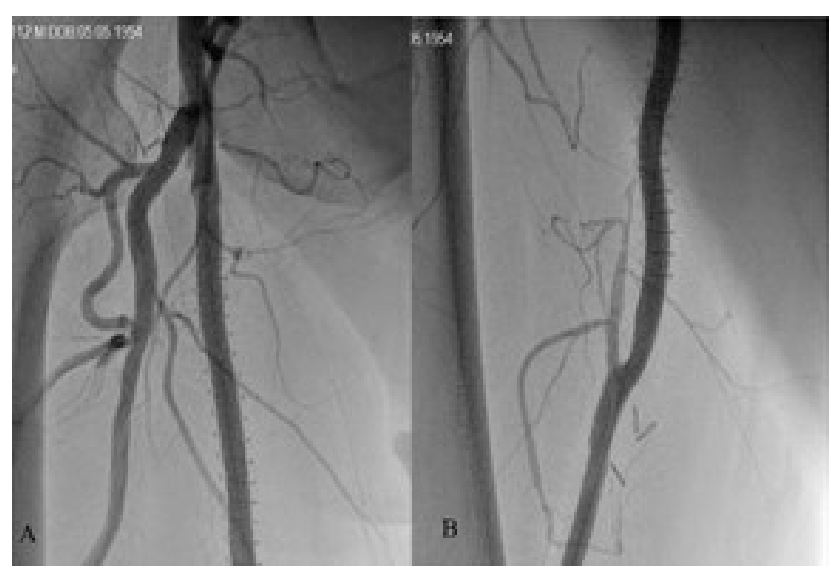

At the end of the control arteriography after both procedures, in the presence of severe residual flowlimiting stenosis, balloon angioplasty was performed, and in cases where it was not sufficient, selfexpandable nitinol stent implantation was performed.

\section{Post-operative follow-up}

Low molecular weight heparin was administered routinely for 5 days post-operatively in all patients. In addition, acetylsalicylic acid (ASA) $100 \mathrm{mg}$ was started to be administered. Vitamin $\mathrm{K}$ antagonist was initiated in patients with atrial fibrillation. After discharge dual antiaggregant therapy (clopidogrel $75 \mathrm{mg}$, ASA 100mg) was continued in patients who were not started on a vitamin $\mathrm{K}$ antagonist.

The patients' follow-ups at the 3rd, 6th and 12th months were recorded.

The primary endpoint of the study was the technical success of endovascular therapy, defined as complete or near-complete revascularization (classified as the completing the revascularization without any residual stenosis greater than $30 \%$ or flow-limiting stenosis at the final angiography) of the occluded artery, and the patency rate of the target vessel at the end of 12 months (primary patency, PP).

Clinical success, defined as improvement of the Rutherford classification in one or more classes compared to the preprocedural Rutherford classification at the first month follow-up, was determined as mortality and unplanned amputation within the first 30 days and patency (secondary patency, SP) of the target vessel after the need for additional intervention within 12 months.

\section{Statistical Analysis}

The NCSS (Number Cruncher Statistical System, 2007, Kaysville, Utah, USA) program was used for statistical analysis. While evaluating the study data, descriptive statistical methods (mean, standard deviation, median, frequency, ratio, minimum, maximum) as well as the Mann Whitney $U$ test were used for the comparison of non-normally distributed parameters between the two groups. The Pearson Chi-Square test was used to compare qualitative data. Significance was evaluated at $p<0.001$ and $p<0.05$ levels.

\section{Results}

A total of 13 patients, 11 (84.6\%) males and 2 (15.4\%) females, who had a previous FPB and developed ALI during follow-up were included in the study. Of the 13 patients included in the study, 8 patients underwent RT, while 5 patients underwent CDT.

The mean age of the patients participating in the study was $64.5( \pm 7.4)$ years. There was no significant difference between the mean age of the patients who underwent RT or catheter-mediated thrombolysis $(p=0.87)$. There was no significant difference between the groups in terms of demographic data or comorbidities. Demographic data and additional diseases of the patients included in the study are given in Table 1.

Table 1. Patients Demographics and Comorbidities

$\begin{array}{llll}\text { Age }(y) & \begin{array}{l}\text { CDT }(n=5) \\ (38.5 \%)\end{array} & \begin{array}{l}\text { RT }(n=8) \\ (61.5 \%)\end{array} & \text { P value } \\ & 64 \pm 8.7 & 64.8 \pm 7.1 & 0.87 \\ \text { Males } & 5(100 \%) & 6(75 \%) & 0.49 \\ \text { Hypertension } & 4(80 \%) & 6(75 \%) & 0.84 \\ \text { Hyperlipidemia } & 5(100 \%) & 4(50 \%) & 0.11 \\ \text { CAD } & 4(80 \%) & 4(50 \%) & 0.57 \\ \text { DM } & 4(80 \%) & 2(25 \%) & 0.10 \\ \text { COPD } & 2(40 \%) & 5(62.5 \%) & 0.59 \\ \text { AF } & 1(20 \%) & 2(25 \%) & 0.84 \\ \text { Current Smoker } & 5(100 \%) & 6(75 \%) & 0.49\end{array}$

CDT: catheter directed thrombolysis, RT; rheolytic thrombectomy, Y; year, CAD; coronary artery disease, DM; diabetes mellitus, COPD; chronic obstructive pulmonary disease, AF; atrial fibrillation

When the patients were evaluated according to Rutherford acute ischemia criteria at the time of admission to the emergency department, 4 patients 
were classified as $2 \mathrm{a}(30.8 \%)$ and 9 patients as $2 \mathrm{~b}$ (69.2\%). There was no significant difference between the groups in terms of Rutherford criteria $(p=0.57)$.

All patients included in the study had a history of unilateral FPB with an $8 \mathrm{~mm}$ ring polytetrafluoroethylene (PTFE) graft. Seven patients had a history of right lower extremity bypass, while 6 patients had a history of left lower extremity FPB $(p=0.72)$. The mean FPB age was $45.9 \pm 14.9$ months. There was no significant difference between the groups in terms of FPB age $(p=0.82)$.

The median time from the onset of ALI symptoms to the treatment of the patients was determined as 4 (min-max 2-8) hours. There was no significant difference between the groups in terms of time until the procedure $(p=0.31)$.

An additional dose of thrombolytic infusion was administered to 4 patients who underwent RT because they had residual thrombi.

In addition to RT and CDT treatments, endovascular intervention was performed in 5 patients (38.5\%) at the end of the procedure. Flat balloon angioplasty was performed on the proximal and distal anastomosis sites in four patients, while self-expandable stent implantation was performed on the distal anastomosis site in one patient. There was no significant difference between the two groups in terms of the need for additional intervention.

The technical success rate was determined as 92.3\% (n=12). Surgical embolectomy as well as endarterectomy and patchplasty procedures were performed in the proximal and distal anastomosis regions in one patient whose thrombus could not be resolved despite the application of thrombolytic infusion for 24 hours after RT. There was no significant difference between the groups in terms of technical success $(p=0.41)$.

The mean hospital stay was found to be $56.3 \pm 16.5$ hours. There was no significant difference between the groups in terms of length of stay $(p=0.06)$. In the subgroup analysis, patients admitted with Rutherford $2 a(42 \pm 15.5)$ had a shorter hospital stay compared

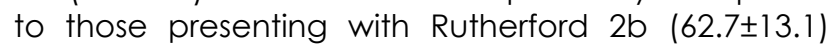
$(p=0.03)$.

Total PP at 6 th and 12 th months was $92.3 \%$ and $69.2 \%$, respectively. When the patients who underwent RT and CDT were compared, the 6-month PP values were $87.5 \%$ and $80 \%$, while the 12 -month PP values were $75 \%$ and $60 \%$. There was no statistically significant difference between the groups in this respect $(p=0.58)$. Total SP at 6 th and 12 th months was $100 \%$ and $84.6 \%$, respectively. When the patients who underwent RT and CDT were compared, 6-month SP values were $100 \%$ in both groups, while 12-month SP values were $87.5 \%$ in the RT group and $80 \%$ in the CDT group. There was no statistically significant difference between the groups ( $p=0.73)$. (Table 2)
Table 2. Kaplan-Meier's estimates of early and late outcome in overall series

\begin{tabular}{|c|c|c|c|}
\hline & 6 months & 12 months & $P$ value \\
\hline Overall Primary Patency & $92.3 \%$ & $69.2 \%$ & \\
\hline \multicolumn{4}{|l|}{ Primary Patency } \\
\hline CDT & $80 \%$ & $60 \%$ & \multirow[t]{2}{*}{0.58} \\
\hline RT & $87.5 \%$ & $75 \%$ & \\
\hline Overall Secondary Patency & $100 \%$ & $84.6 \%$ & \\
\hline \multicolumn{4}{|l|}{ Secondary Patency } \\
\hline CDT & $100 \%$ & $80 \%$ & \multirow[t]{2}{*}{0.73} \\
\hline RT & $100 \%$ & $87.5 \%$ & \\
\hline
\end{tabular}

CDT: catheter directed thrombolysis, RT; rheolytic thrombectomy

Although no major hemorrhagic complication was encountered in any patient, localized hematoma and ecchymosis were observed at the vascular sheath insertion site, which did not require interruption of the thrombolytic infusion. No additional surgical intervention was performed for this condition, and ecchymosis and hematoma conditions of the patients regressed in the follow-ups.

Hematuria was observed in 5 (62.5\%) patients who underwent RT. And it was regressed with fluid resuscitation. Bradycardia and acute renal failure were not observed in any patient. An unplanned amputation was performed in a patient who underwent RT. This patient came in with Rutherford $2 \mathrm{~b}$. After the procedure, distal metatarsal amputation was planned. However, below-knee amputation was performed due to defects in wound healing after amputation.

No mortality was observed during the study.

\section{Discussion}

In the current study we found that endovascular procedures in acute lower extremity graft occlusions can be performed with high success rates and comparable primary patency rates regardless of the type of endovascular procedure performed.

There are also studies on patients with acute on chronic limb ischemia and treated with endovascular manner showing $85-97 \%$ technical success rates $(10,11)$. One of the reasons for the high technical success achieved in the current study can be the short latency duration for the intervention. Early intervention can lead to early initiation of thrombolytic therapy which may increase the chances of success (6). There are also studies which showed lower technical success rates as $38-70 \%(12,13)$. The low success rate in these studies may be explained by the length of time to initiate the operation and the smaller PTFE grafts diameter.

Thrombolytic infusion, can be given directly through venous and arterial routes via catheters, or it can be given into the lesion through RT catheter. In a study by Lian et al, primary patency was $60 \%$ for 6 months and 76.67 for 12 months in patients treated with CDT method. Again in the same study, it was stated that 
CDT method can be used safely and effectively in primary treatment, especially for small vessels in acute arterial thromboembolism (14). However, Vakhitov et al followed the patients they included in their study for an average of 126.3 months. In the long-term followup, the CDT method was reported as insufficient and it was reported that additional methods may be needed to provide adequate distal perfusion (15).

Although the symptoms regressed in 9 patients who underwent the procedure, balloon angioplasty was applied to the stenosis in the proximal and distal FPB graft in 4 patients with additional lesions, and postprocedure stent was applied in 1 patient. There was no statistically significant difference between the two groups in terms of the need for additional intervention.

Braitwaithe et al. reported that they treated $50 \%$ of the patients within 4 hours with bolus dose TPA in the treatment of acute ischemia (16). Gürsoy et al. administered a bolus dose of TPA on the lesion in a patient who underwent surgical embolectomy 6 times within 2 days and developed distal embolism again, and reported that this method was applicable in a selected patient group (17). In our experience, bolus administration of high-dose IPA into the lesion will accelerate thrombolysis and patients with acute leg ischemia will be treated more easily and quickly compared to surgery. The catheter can be embedded in the thrombus in order to provide full benefit to the patients and to make the thrombolytic infusion at the maximum concentration, especially during the continuation of the treatment. In addition to early and accurate diagnosis in the treatment of acute embolic diseases, the chosen treatment method is also determinative on mortality and morbidity $(2,7)$.

Symptom onset and processing times were similar in both groups, and there was no statistically significant difference between them. Considering the treated patients, the best results were seen in patients who applied and were processed in the first 6 hours after symptom onset (18). In case of perfusion, especially after a long ischemia period, compartment syndrome and related hypoesthesia of the foot and paresis of the finger may develop due to the development of reperfusion damage. In addition, acidosis, acute renal injury (ARI), pulmonary insufficiency, extremity loss and possible death may develop $(7,19)$. No patients in the study group developed compartment syndrome, ARI, or acidosis.

Although we did not observe these complications in our patients. Those complications can be observed after endovascular procedures especially after RT. In the study by Odeh et al, including a total of 243 patients, the need for embolectomy and the incidence of compartment syndrome were lower in the group supported by RT. It was also reported that less bleeding, shortened lysis time, and a decrease in hospitalization time were detected (20). In another study on venous system thrombi, it was reported that catheter-mediated thrombolytic and rheolytic thrombectomy may increase hemolysis and cause ARI
(21).

Although the success of endovascular thrombolysis techniques is shown to be higher in native vessels in some studies, higher technical success rates are observed in femoropopliteal bypass grafts compared to native vessels, similar to our study $(15,22)$.

There is no clear evidence in the literature in favor of thrombolysis or surgery (23). Looking into the literature, 30-day amputation rates are around $10-30 \%$ when new treatment methods are included and thrombolysis is recommended, if it isbe performed without delay in native artery ischemia that occurred in less than 14 days (9). It is thought that endovascular intervention reduces the complication rate because it allows rapid diagnosis and treatment in patients.

Small sample size and the retrospective design are the major limitations of the study.

\section{Conclusion}

Endovascular therapy can be preferred in the treatment of selected patient groups due to its less invasiveness compared to surgery, early mobilization, and low mortality and morbidity rates. Although it is not possible to make a choice between surgical or endovascular methods, we believe that detailed studies are needed to make a decision on this issue.

\section{References}

1.Norgren L, Hiatt WR, Dormandy JA, et al. Inter-Society consensus for the management of peripheral arterial disease (TASC II). J Vasc Surg 2007;45(Suppl S):S5-67.

2.Hage AN, McDevitt JL, Chick JFB, et al. Acute Limb Ischemia Therapies: When and How to Treat Endovascularly. Semin Intervent Radiol. 2018;35(5):453-460. doi: 10.1055/s-0038-1676321.

3.Atay $M$, Gürsoy M, Bakuy $\vee$, ve ark. Akut üst ekstremite arteryel embolileri: 2 yıllık klinik deneyimimiz. Bakırköy Tıp Dergisi 2016;12(4):202206.

4.T.J. Fogarty, J.J. Cranley, R.J. Krause, et al. A method for extraction of arterial emboli and thrombi Surg Gynecol Obstet, 116 (1963), pp. 241-244.

5.Umemoto T, Hirasawa K, Matsuda Y, et al. A novel fully percutaneous thrombectomy technique with balloon occlusion guiding catheter and over-the-wire Fogarty catheter for acute limb ischemia. Journal Of The American College Of Cardiology 2017;70(18): Suppl B, pp:8149

6.Olinic DM, Stanek A, Tătaru DA, et al. Acute Limb Ischemia: An Update on Diagnosis and Management. J Clin Med. 2019;8(8):1215. Published 2019 Aug 14. doi:10.3390/jcm8081215

7.McNally MM, Univers J. Acute Limb Ischemia. Surg Clin North Am. 2018 Oct:98(5):1081-1096. doi: 10.1016/j.suc.2018.05.002. PMID: 30243449 .

8.Bayır A, Ak A. Acil olgularda trombolitik tedavi. Genel Tıp Derg 2003; 13: 81-88.

9.Working Party on Thrombolysis in the Management of Limb Ischemia. Thrombolysis in the management of lower limb peripheral arterial occlusion--a consensus document. J Vasc Interv Radiol. 2003; 14 (9 Pt 2):S337-49. doi: 10.1016/s1051-0443(07)61244-5. PMID: 14514841.

10.Poursina O, Elizondo-Adamchik H, Montero-Baker M, et al. Safety and efficacy of an endovascular-first approach to acute limb ischemia. J Vasc Surg. 2021 May;73(5):1741-1749. doi: 10.1016/j. jvs.2020.10,002. Epub 2020 Oct 15. PMID: 33068768.

11.Koraen L, Kuoppala M, Acosta S, et al. Thrombolysis for lower extremity bypass graft occlusion. Journal Of Vascular Surgery 
2011;54(5): 1339-1444

12.Vesely TM, Idso MC, Audrain J, et al. Thrombolysis versus Surgical Thrombectomy for the Treatment of Dialysis Graft Thrombosis: Pilot Study Com - paring Costs. Journal of Vascular and Interventional Radiology 1996:7(4):507-512

13.YImaz G, Sincer I, Erdal E. Catheter-directed intra-arterial thrombolysis for lower extremity arterial occlusions. ol J Cardiol 2019; 22: 54-9. DOI: 10.14744/ Anatol J Cardiol 2019. 63296

14.Lian WS, Das SK, Hu XX, et al. Efficacy of intra-arterial catheterdirected thrombolysis for popliteal and infrapopliteal acute limb ischemia. J Vasc Surg 2020;71 (1):141-148

15.Vakhitov D, Suominen V, Korhonen J, et al. Independent factors predicting early lower limb intra-arterial thrombolysis failure. Ann Vasc Surg 2014; 28: 164-9.

16.Braithwaite BD, Buckenham TM, Galland RB, et al. Prospective randomized trial of high-dose bolus versus low-dose tissue plasminogen activator infusion in the management of acute limb ischemia. Thrombolysis Study Group. Br J Surg. 1997 May;84(5):646-50. PMID: 9171752.

17.Gürsoy $M$, Bakuy V, Atay $M$, et al. Hybrid approach in patients with recurrent brachial artery embolism. Ulus Travma Acil Cerr Derg 2014;20(1):56-58

18.Saraç A, Akan H, Demirağ MK, ve ark. Akut Atardamar Tıkanıklıklarında Lokal Trombolitik Tedavi. J. Exp. Clin. Med. 2004; $21(2): 78-83$

19.Yetkin U, Gürbüz A. Akut Arter Tıkanmalarına Genel Bakış. Van Tıp Dergisi 2002;9(1)

20.Odeh K, Ullah R, Hashim H, et al. Comparative Study on CatheterDirected Thrombolysis - Continuous Tissue Plasminogen Activator Versus Angiojet Catheter Power Pulse Spray Rheolytic Thrombectomy Outcome Study: Single-Center Experience. Journal of the American College of Cardiology. 2017;69(11):2016. doi:10.1016/s07351097(17)35405-0

21.Shen $Y$, Wang $X$, Jin S, et al. Increased risk of acute kidney injury with percutaneous mechanical thrombectomy using AngioJet compared with catheter-directed thrombolysis. Journal of Vascular Surgery: Venous and Lymphatic Disorders 2019;7(1):29-37

22.Plate G, Oredsson S, Lanke J. When is thrombolysis for acute lower limb ischemia worthwhile? Eur J Vasc Endovasc Surg 2009; 37: 206-12

23.Darwood R, Berridge DC, Kessel DO, et al. Surgery versus thrombolysis for initial management of acute limb ischemia. Cochrane Database Syst Rev. $2018 ; 10 ; 8(8): C D 002784$ 